\title{
INTRASEASONAL VARIATION IN A POPULATION OF FOUNTAINEA RYPHEA (CRAMER) (LEPIDOPTERA, NYMPHALIDAE)
}

\author{
Astrid Caldas ${ }^{1}$
}

\begin{abstract}
A different approach was used for the key-factor method in a population study of the tropical butterfly Fountainea ryphea (Cramer, [1776]) (Lepidoptera, Nymphalidae), marking 20 artificial cohorts to identify the mortality levels and associated instars responsible for the variation in numbers within the season of occurrence, when generations overlap broadly. Highest mortality was detected during first instar in 13 cohorts; during second instar in three cohorts; third and fourth instars suffered highest mortality twice. Results showed that first instar mortality due to rainfall and predation, and parasitism on fourth instar could be the main factors promoting differences in number between cohorts throughout the season, although no density-dependent processes could be identified.

KEY WORDS. Bracon, k-factor, parasitism, predation
\end{abstract}

Among the methods developed for the analysis of factors acting on populations, life tables are especially useful to evaluate mortality in each life stage for a constantly reproductive population (ROYAMA 1981). Three types of results are important: 1) the determination of mortality acting on each life stage and their sources; 2) the relative importance of these sources in the density variations between generations (key-factors) and 3) the role of these sources in the natural regulation of density (regulation processes). Recent reviews (STILING 1988; HASSEL et al. 1989) show that most studies using life tables involve temperate insects, mainly Lepidoptera. They analyze both agricultural (BANERJEE 1979; BARLOw et al. 1986) and natural systems (BAUER 1985; WARREN et al. 1986), the former being dominant in number. Some of them include only immature stages due to difficulties in estimating adult populations.

The main reason for the dominance of temperate insects in this kind of study is the fact that, in their populations, one can more easily identify generations and treat them separately. The construction of one life table for each generation is necessary for the identification of the key-factor acting on that particular species. In many tropical insects it is difficult to do the same, because generations usually overlap and even the number of generations per season is hard to be accurately identified. This restricts the use of life tables in these populations.

A different approach was used for the key-factor method in a population study of the tropical butterfly Fountainea ryphea (Cramer, [1776]) (Lepidoptera, Nymphalidae). The method has been originally used to identify the main factor responsible for differences in numbers between generations (MORRIS 1959; VARLEY \& GRADWELl 1960). As it was not possible to state the real number of

1) Departamento de Biologia Animal e Vegetal, Universidade do Estado do Rio de Janeiro. Rua São Francisco Xavier 524, 20559-900 Rio de Janeiro, Rio de Janeiro, Brasil.

Revta bras. Zool. 13 (2): 399 - 404, 1996 
generations per year or measure mortality in pupae and adults, or the effects on individual egg-laying rate, the method was used in a different way, all the basic assumptions being taken into account. Since generations overlap broadly in $F$. ryphea populations, rather than trying to identify them, I followed artificial cohorts in the field to assess the factors influencing fluctuations in a population within a season. The advantage of this approach is the fact that, since some factors act with different intensities at different times, their effect on the population numbers can be estimated for each cohort, instead of in average for intervals along the whole season - as it is usually done in life table studies with tropical insects. Here, using age-specific instead of time-specific life tables, it could be determined when each factor had its higher killing power throughout the season, and when it was surpassed by other factor.

This kind of analysis was possible because $F$. ryphea populations have very particular characteristics. It is a highly seasonal butterfly in Southern Brazil, occurring usually from November through May. The eggs are laid singly, rarely more than one per leaf (CALDAS 1994), which enabled me to follow each individual throughout its development. Although very simple, this approach had not been used before.

\section{MATERIAL AND METHODS}

The study area consisted of a semideciduous subtropical moist forest in successional mosaic, left undisturbed for the past 12 years. Along the central $1,160 \mathrm{~m}$ trail of the $2.5 \mathrm{~km}^{2}$ Reserva Mata de Santa Genebra, Campinas, São Paulo state, Brazil (22 $54^{\prime} \mathrm{S}$ and $47^{\circ} 05^{\prime} \mathrm{W}$, elevation $\left.650 \mathrm{~m}\right), 186$ individuals of Croton floribundus Spreng (Euphorbiaceae), the larval food plant of $F$. ryphea, were marked with numbered plastic tags.

Censuses were conducted once a week in order to establish the cohorts. During each census all leaves of all plants were searched for newly eclosed first instar larvae, which were individually identified by a numbered plastic band on the petiole of their perching leaf. If more than one larva were on the same leaf, the position and instar of each one was noted. Twenty cohorts were obtained from January to May 1989 (period when the number of individuals was equal or higher than five in the whole area, a number considered satisfactory for this study). The cohorts were followed at intervals that started weekly and reached every other day when $F$. ryphea larvae were abundant.

From direct observations in the field and from inferences based on the disappearance pattern of the larvae, principal causes of mortality were listed for each age class. It is important to stress that identifying the reasons of mortality was not my main goal. The goal was to identify which instar(s) accounted more for the variation in numbers of immatures throughout the season. Assigning mortality factors to each instar was a more tentative task, although some of these factors, as noted, could be identified without any doubt. The mortality factors assigned were: for first instar, rainfall and predation; second instar, rainfall and predation; third instar, virus and predation; fourth instar, parasitism and predation. In all life tables, the role of parasitoids and rainfall was actually observed, virus was inferred from 
the general aspect of individuals found dead (C.F. Andrade, personal communication), and predation was inferred when no other explanation existed for the disappearance of a larva. This is common procedure in key-factor studies (see DANTHANARAYANA 1983 and WARREN et al. 1986). Also because larvae are very sedentary and seldom large larvae were found in previously examined plants, it seemed that missing eggs and young larvae are the result of death rather than dispersal or incomplete censusing. Fifth instar larvae disperse off the host plant to pupate, and pupae were not censused, because a larger-scale population ecology study was taking place simultaneously (CALDAS 1995b), and any artificial procedure influencing the natural behavior of fifth instar larvae would affect the number of adults in the area, and also the next offspring.

Horizontal (age-specific) life tables were constructed for the cohorts of $F$. ryphea larvae. From these life tables, k-values (killing power values) were calculated (VARLEY \& GRADWELL 1960; 1970) for the mortality factors throughout the season. Then a search was made for key-factors responsible for main changes in numbers of the population during the same period. As a consequence of the fifth-instar dispersal, the total $k$-value in the tables is a total only for the analyzed instars, not for the whole life cycle.

\section{RESULTS}

Highest mortality occurred mostly in first instar larvae along the whole season (13 out of the 20 cohorts, table I). Second instar larvae from cohorts marked on February 19, March 27 and April 11 suffered higher mortality than other instars. Third instar had highest mortality in cohorts marked March 04 and April 08. Fourth instar larvae suffered higher levels of mortality twice, in individuals from January 19 and February 1 (second and fourth of the marked cohorts). Considering the life cycle of the species (CALDAS 1994), first instar larvae marked on these two days can be estimated to be in fourth instar after 25 to 28 days. That would be February 13 to 15 and February 25 to 28, exactly the period when overall larval population reached its peak at the study area. The braconid parasitoids [genus Bracon Fabricius, (1805)] seem to have responded to this high density with an increased rate of parasitism on fourth instar individuals.

The key-factor analysis made through regression showed that during the study period first instar survival was the best predictor of cohort suvivorship (Tab. II). The key-factor analysis using the coefficient of variation indicates fourth instar larvae as suffering the action of the main factor (Tab. III).

The analysis of mortality in the 20 life tables did not detect any density dependence when tested through $k$-factor method, although fourth instar parasitism seemed to be a response to increased larval population.

\section{DISCUSSION}

It had already been observed that the highest level of mortality for $F$. ryphea was on the first instar, and that there was a high and significant correlation between monthly rainfall indices and total k-values for larvae (CALDAS 1995a). These did 
Table I. K-values for Fountainea ryphea life tables constructed with cohorts at Campinas. (n) Number of individuals forming the cohort; $\left(\mathbf{k}_{\mathbf{x}}\right) k$-value for instar $\mathrm{x} ;(\mathbf{T})$ total $k$-value for the cohort.

\begin{tabular}{cccccccc}
\hline & $\begin{array}{c}\text { 12 Jan } \\
\mathrm{n}=23\end{array}$ & $\begin{array}{c}\text { 19 Jan } \\
\mathrm{n}=13\end{array}$ & $\begin{array}{c}26 \text { Jan } \\
\mathrm{n}=29\end{array}$ & $\begin{array}{c}01 \text { Feb } \\
\mathrm{n}=24\end{array}$ & $\begin{array}{c}15 \text { Feb } \\
\mathrm{n}=74\end{array}$ & $\begin{array}{c}19 \text { Feb } \\
\mathrm{n}=16\end{array}$ & $\begin{array}{c}22 \mathrm{Feb} \\
\mathrm{n}=25\end{array}$ \\
\hline$k_{1}$ & 0.802 & 0.114 & 0.383 & 0.301 & 0.407 & 0.251 & 0.796 \\
$k_{2}$ & 0.000 & 0.222 & 0.235 & 0.301 & 0.140 & 0.477 & 0.301 \\
$k_{3}$ & 0.300 & 0.177 & 0.000 & 0.301 & 0.208 & 0.175 & 0.301 \\
$k_{4}$ & 0.221 & 0.601 & 0.066 & 0.474 & 0.072 & 0.305 & 0.000 \\
$\mathrm{~T}$ & 1.323 & 1.114 & 0.684 & 1.377 & 0.827 & 1.208 & 1.398 \\
\hline & $24 \mathrm{Feb}$ & $02 \mathrm{Mar}$ & $04 \mathrm{Mar}$ & $13 \mathrm{Mar}$ & $16 \mathrm{Mar}$ & $19 \mathrm{Mar}$ & 27 Mar \\
& $\mathrm{n}=35$ & $\mathrm{n}=52$ & $\mathrm{n}=30$ & $\mathrm{n}=18$ & $\mathrm{n}=19$ & $\mathrm{n}=52$ & $\mathrm{n}=11$ \\
\hline$k_{1}$ & 0.642 & 0.375 & 0.247 & 0.214 & 0.279 & 0.301 & 0.343 \\
$k_{2}$ & 0.062 & 0.301 & 0.328 & 0.139 & 0.222 & 0.301 & 0.397 \\
$k_{3}$ & 0.294 & 0.041 & 0.606 & 0.125 & 0.080 & 0.115 & 0.000 \\
$k_{4}$ & 0.294 & 0.045 & 0.000 & 0.080 & 0.097 & 0.156 & 0.000 \\
$\mathrm{~T}$ & 1.292 & 0.762 & 1.181 & 0.558 & 0.678 & 0.873 & 0.740 \\
\hline & $01 \mathrm{Apr}$ & $08 \mathrm{Apr}$ & $11 \mathrm{Apr}$ & $14 \mathrm{Apr}$ & $18 \mathrm{Apr}$ & $03 \mathrm{May}$ & \\
& $\mathrm{n}=28$ & $\mathrm{n}=36$ & $\mathrm{n}=15$ & $\mathrm{n}=22$ & $\mathrm{n}=21$ & $\mathrm{n}=13$ & \\
\hline$k_{1}$ & 0.192 & 0.256 & 0.222 & 0.740 & 0.419 & 0.269 & \\
$k_{2}$ & 0.052 & 0.097 & 0.477 & 0.607 & 0.125 & 0.147 & \\
$k_{3}$ & 0.028 & 0.301 & 0.178 & 0.000 & 0.175 & 0.222 & \\
$k_{4}$ & 0.030 & 0.203 & 0.000 & 0.000 & 0.126 & 0.000 & \\
$\mathrm{~T}$ & 0.302 & 0.857 & 0.877 & 1.347 & 0.845 & 0.638 & \\
\hline & & & & & & & \\
\hline
\end{tabular}

Table II. Key-factor analysis through regression coefficient using 20 horizontal life tables from marked cohorts of Fountainea ryphea at Campinas. (1) First instar; (2) second instar; etc.. (mean) Mean killina bower value ( $k$ ) for the 20 cohorts analvzed.

\begin{tabular}{cccc}
\hline Age & Mean & Regression coefficient on $k$-total & Coefficient of determination \\
\hline $1\left(k_{1}\right)$ & 0.3777 & 0.3786 & 0.3392 \\
$2\left(k_{2}\right)$ & 0.2466 & 0.1570 & 0.0965 \\
$3\left(k_{3}\right)$ & 0.1814 & 0.2399 & 0.2629 \\
$4\left(k_{4}\right)$ & 0.1385 & 0.2245 & 0.1757 \\
\hline
\end{tabular}

Table III. Key-factor analysis through coefficient of variation for the same data.

\begin{tabular}{ccc}
\hline Age & $\begin{array}{c}\text { Average number of } \\
\text { individuals per census }\end{array}$ & $\begin{array}{c}\text { Coefficient of variation for } \\
\text { individuals per census (\%) }\end{array}$ \\
\hline 1 & 27.63 & 54 \\
2 & 11.99 & 59 \\
3 & 7.00 & 79 \\
4 & 4.77 & 87 \\
\hline
\end{tabular}


not account much for between-months variation in density, although first instar mortality is commonly high among Lepidoptera, and is often a key-factor (DANTHANARAYANA 1983; HIGASHIURA 1987). Nevertheless, late instars mortality can also cause fluctuations between generations, as in Colias alexandra W.H. Edwards (Pieridae) (HAYES 1981) and Notocelia roborana Den. and Schiff (Tortricidae) (BAUER 1985), where pupae are the most attacked. The fact that fourth instar was indicated as a key factor through the coefficient of variation analysis is a clear sign that not always the factor promoting the highest mortality is the one responsible for the variation between generations.

Second instar larvae may suffer high predation because they are already too large to take full benefit from the disguise provided by the midvein and the "frass chain" built from first instar on. On the other hand, they still do not have the protection offered by the leaf roll, usually built from fourth instar on (CALDAS 1994). Fourth instar larvae are the target of braconid wasps (Bracon sp.), which oviposit inside the larval body through the leaf roll.

One interesting point is that the results for the intra-seasonal variation in this population are completely different from the results found for the variation between years, using time-specific life tables (CALDAS 1995b). On a different scale, it seems that other instars play a different role on the population.

Many studies with insects fail to identify density dependent processes acting on the populations (STILING 1988), but this does not necessarily mean that they are not present. Studies involving a small number of generations rarely detect densitydependent processes, even when they exist. BANERJEE (1979) studied a population of Andraca bipunctata Walker (Lepidoptera, Bombycidae) for 3 years in India and was not able to identify any density dependence, but he recognized that his metodology could not be adequate. Actually, population regulation is more likely to be identified when studies cover a high number of generations. HASSELL et al. (1989) showed that among insect studies the percentage of success in detecting density dependence increases with the number of generations followed. There is not a recommended number of generations to be studied, though, mainly because density dependence can occur in instant processes, which could be difficult to identify.

Frequently there is more than one factor acting simultaneously on a certain population (STILING 1988). Since the interactions between those factors are not always known, sometimes it is difficult to determine which one is more important for that specific population. Factors acting on the same instar may turn quantitative analysis very hard, and if they have similar intensities it will be almost impossible to tell if one is more important than the other. For this population of $F$. ryphea the methods and duration of study did not allow the identification of definite regulating and key factors. But some important mortality factors had their intensities quantified and their role along the season defined, serving as a basis for further speculation on the processes responsible for variation in abundance of tropical insect populations.

ACKNOWLEDGMENTS. I thank the Fundação José Pedro de Oliveira for the permit to develop research inside the Reserve, the manager and guards for their help; Dr. Angélica Maria P.M. Dias for identification of the braconids; and J.P. Dempster, Gerardo Lamas, Robert K. 
Robbins, Monique Van Sluys, and Henk Wolda for comments on the manuscript. This project was part of my doctoral dissertation, and I thank Woodruff W. Benson for his thorough advise throughout the research. Partially funded by FAEP/UNICAMP (grant kindly requested by W.W. Benson exclusively for my project) and a CAPES -Ministry of Education/Brazil predoctoral fellowship.

\section{REFERENCES}

BANERJEe, B. 1979. A key-factor analysis of population fluctuations in Andraca bipunctata Walker (Lepidoptera: Bombycidae). Bull. Ent. Res. 69: 195-201.

Barlow, N.D.; R.A. FrenCH \& J.F. PEARSON. 1986. Population ecology of Wiseana cervinata a pasture pest in New Zealand. J. Appl. Ecol. 23: 415-431.

BAUER, G. 1985. Population ecology of Pardia tripunctana Schiff. and Notocelia roborana Den. and Schiff. (Lepidoptera, Tortricidae) - an example of "Equilibrium species". Oecologia 65: 437-441.

CAlDAS, A. 1994. Biology of Anaea ryphea (Nymphalidae) in Campinas, Brazil. J. Lepid. Soc. 48 (3): 248-257.

1995a. Mortality of Anaea ryphea (Lepidoptera: Nymphalidae) immatures in Panama. J. Res. Lepid. 31 (3-4): 195-204.

1995b. Population ecology of Anaea ryphea (Nymphalidae): immatures at Campinas, Brazil. J. Lepid. Soc. 49 (3): 234-245.

DANTHANARAYANA, W. 1983. Population ecology of the light brown apple moth, Epyphias postvittana (Lepidoptera: Tortricidae). J. Anim. Ecol. 52: 1-33.

Hassell, M.P.; J. LatTo \& R.M. MAY. 1989. Seeing the wood for the trees: detecting density dependence from existing life-table studies. J. Anim. Ecol. 58: 883-892.

HAYES, J.L. 1981. The population ecology of a natural population of the pierid butterfly Colias alexandra. Oecologia 49: 188-200.

Higashiura, Y. 1987. Larval densities and a life-table for the gipsy moth, Lymantria dispar, estimated using the head-capsule collection method. Ecol. Entomol. 12: 25-30.

MORRIS, R.F. 1959. Single factor analysis in population dynamics. Ecology 40: 580-588.

ROYAMA, T. 1981. Evaluation of mortality factors in insect life table analysis. Ecol. Monographs 51: 495-505.

Stiling, P. 1988. Density-dependent processes and key factors in insect populations. J. Anim. Ecol. 57: 581-593.

VARLEY, G.C. \& G.R. GRADWELl. 1960. Key factors in population studies. J. Anim. Ecol. 29: 399-401.

1970. Recent advances in insect population dynamics. Ann. Rev. Entomol. 15: 1-24.

WARREN, M.S.; E. Pollard \& T.J. BibBy. 1986. Annual and long-term changes in a population of the wood white butterfly Leptidea sinapis. J. Anim. Ecol. 55: 707-719.

Recebido em 30.VIII.1995; aceito em 10.IX.1996. 